\title{
A new host and faunistic record of the big-headed fly Nephrocerus flavicornis ZETTERSTEDT (Pipunculidae, Diptera) from Romania
}

\author{
Levente-Péter KoLCSÁR
}

\begin{abstract}
Summary: The cranefly Tipula (Lunatipula) helvola Loew (Tipulidae, Diptera) was identified as a new host for big-headed fly Nephrocerus flavicornis ZetTERStedT (Pipunculidae, Diptera). This big-headed fly is noted as new to Romania.
\end{abstract}

Keywords: big-headed flies, Tipulidae, Tipula, first record

\section{Introduction}

The genus Nephrocerus ZetTERSTEDT represent a basal lineage within the Pipunculidae (big-headed flies) (Skevington 2005, Skevington et al. 2007) and only within the past decade it has been discovered that the members of this genus are endoparasitoids of adult crane flies (Tipulidae, Diptera) (KeHLMAIER and Floren 2010, KoENIG and Young 2007, Skevington 2005). Three Nephrocerus species are known to occur in Europe (Grootaert and De Meyer 1986). A larva of Nephrocerus scutellatus was found in the abdomen of a female Tipula (Lunatipula) helvola LoEw, and a Nephrocerus flavicornis larva was extracted from a female Tipula (Beringotipula) unca WIEDEMANN (Kehlmaier and Floren 2010). Of these two bigheaded fly species only $N$. scutellatus (MACQUART) was reported previously from Romania (MEYER 2017).

\section{Material and methods}

Specimens were collected in the Mureş Valley near to Andreneasa $\left(46.9614^{\circ} \mathrm{N} 25.0369^{\circ} \mathrm{E}\right)$, Romania on the 25th July 2017. The adult Nephrocerus flavicornis was pinned, whilst the larva and the host, Tipula helvola were preserved in $98 \%$ ethanol. The material is stored in the Diptera Collection of the Faculty of Biology and Geology, Babeş-Bolyai University, ClujNapoca, Romania (DCBBU).

\section{Results}

A male Nephrocerus flavicornis ZeTTERSTEDT (Fig. 1) was collected in the Mureş Valley near to Andreneasa, which represent the first record from
Romania. In the same location two parasitized female Tipula (Lunatipula) helvola LoEw were observed and later collected. The females were noted to sit on ferns and showed a reluctance to fly and would only do so after prolonged disturbance. They were observed to fly awkwardly and only flew a short distance (max $1.5 \mathrm{~m}$ ). It was observed that the abdomens of these parasitized females were notably distended in the first third, while in non-parasitized females the abdomen is always widest in the middle or a little after the middle, which allowed easy separation of parasitized females in the field. Upon catching the parasitized females a Nephrocerus larva immediately vacated one of the hosts (Fig. 2). Later the larvae were identified as $N$. flavicornis, based on the shape of the cephaloskeleton (KeHLMaIER and FlOREN 2010), which was previously unknown to parasitize Tipula helvola.

\section{Aknowledgements}

The author thank to EDINA TöRÖK for helping collecting specimens. I thank Pete Boardman for his comments on the text.

\section{References}

Grootaert P. and De Meyer M. (1986) On the taxonomy and ecology of Nephrocerus ZETTERSTEDT (Diptera, Pipunculidae) with a re-description of $N$. lapponicus and a key to the European species. Bulletin van het Koninklijk Belgisch Instituut voor Natuurwetenschappen, Entomologie, 56: 85-91.

Kehlmaier C. and Floren A. (2010) Pipunculidae (Diptera) collected by canopy-fogging in the Białowieża Forest (Poland), including first host records and larval descriptions of two Palaearctic Nephrocerus Zetterstedt. Studia dipterologica 16: 169-181. 


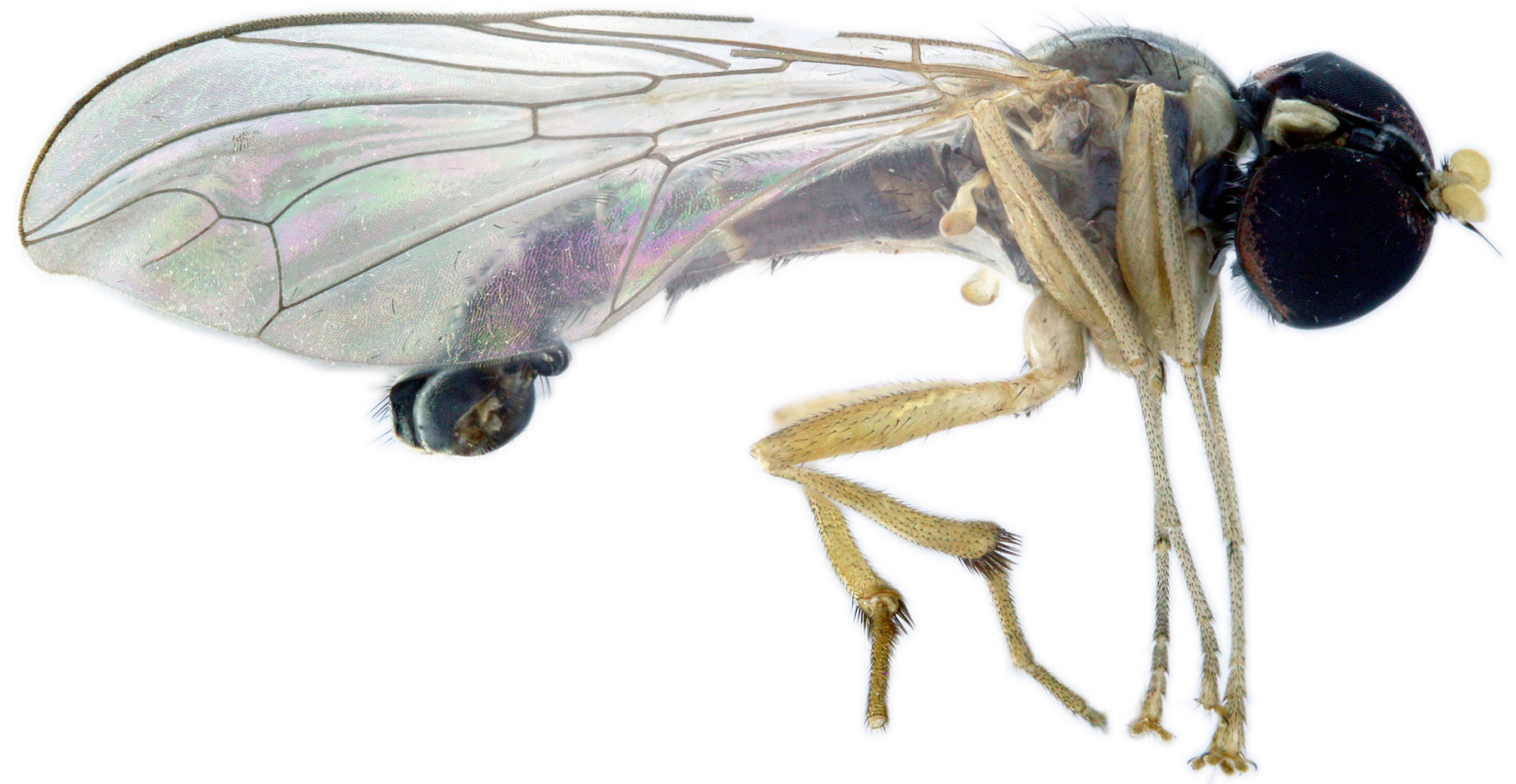

Fig. 1. Nephrocerus flavicornis ZETTERSTEDT male.

Koenig D. P. and Young C. W. (2007) First observation of parasitic relations between big-headed flies, Nephrocerus ZetTerstedt (Diptera: Pipunculidae) and crane flies, Tipula Linnaeus (Diptera: Tipulidae Tipulinae), with larval and puparial descriptions for the genus Nephrocerus. Proceedings of the Entomological Society of Washington 109(1): 52-65.

Meyer, M. (2017) Fauna Europaea: Pipunculidae. In: PaPe T. and BeuK P. (eds.) Fauna Europaea: Diptera, Brachycera. https://fauna-eu.org/ Accesed on 09.11.2017

Skevington J.H. (2005) Revision of Nearctic Nephrocerus Zetterstedt (Diptera: Pipunculidae). Zootaxa 977(1): 1-36.

Skevington J.H., Kehlmaier C. and Stahls G. (2007) DNA Barcoding: Mixed results for big-headed flies (Diptera: Pipunculidae). Zootaxa 1423(1): 1-26.
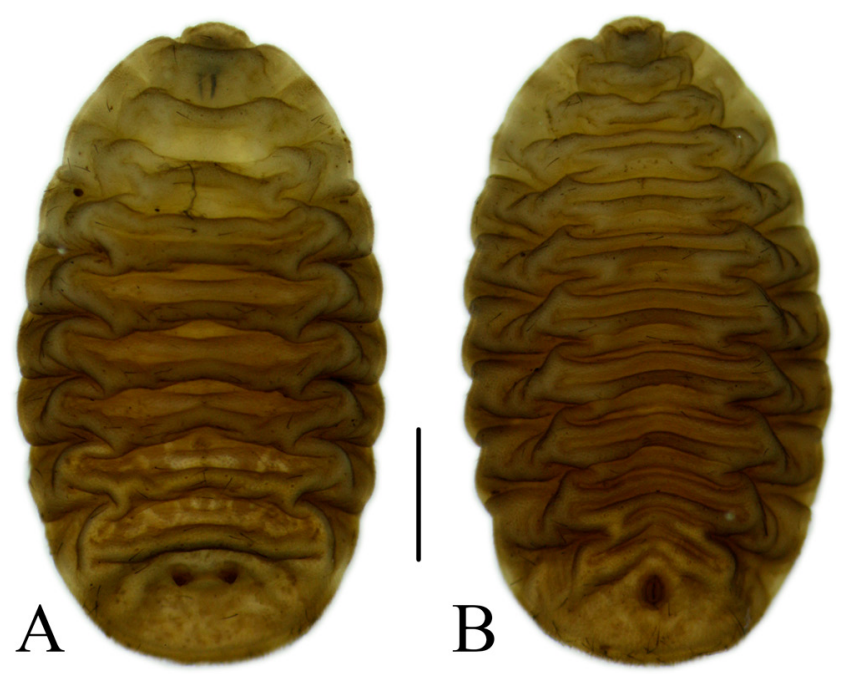

Fig. 2. Nephrocerus flavicornis Zetterstedt larva. A. dorsal view. B. ventral view. Scale bar $1 \mathrm{~mm}$.

Levente-Péter Kolcsár

Hungarian Department of Biology and Ecology, Centre of Systems Biology,

Biodiversity and Bioresources,

Babeș-Bolyai University, Clinicilor 5-7,

Cluj-Napoca, Romania

E-mail: kolcsar.peter@gmail.com

Received: 30.01.2018

Accepted: 15.03.2018

Published online: 31.12 .2018

Published: 31.12.2018

Online article number: ER22201802

doi: 10.24193/entomolrom.22.2 